ISSN 0258-7122

Bangladesh J. Agril. Res. 34(2) : 303-311, June 2009

\title{
EFFECTS OF SEED TREATMENT AND SOIL APPLICATION WITH SOME INSECTICIDES ON STEMFLY AND POD BORERS ON MUNGBEAN
}

\author{
M. A. ZAHID ${ }^{1}$, M, A. I. SARKER ${ }^{2}$, M. M. ISLAM ${ }^{3}$ \\ M. A. HOSSAIN ${ }^{4}$ AND M. R. BEGUM ${ }^{5}$
}

\begin{abstract}
For controlling stemfly (Opheoniyia phaseoli) and pod borers (Helicoverpa armigera \& Maruca vitrata of mungbean insecticides Carbofuran, Carbosulfan, and Phenyl Pyrazol were applied as seed treatment and soil application during kharif II season (August to December) in 2004 and 2005 at Burirhat, Rangpnr. In two years, stemfly infested 86.67-93.33 percent rnunghean plants and caused 26.90-27.09 percent stem tunneling in untreated plots. Carbofuran in both seed treatment and soil application had similar effect on stemfly resulting 1.4 to 7.0 and 1.4 to 4.57 times less damage and stem tunneling, respectively, than the control. Pod borer damage did not differ significantly among the treatments in 2004, but differed in the second year. The yield of mungbean was significantly higher by the soil application of Corbofuran followed by the seed treatment by the same insecticides. But soil application of Carbofuran proved to be economical.
\end{abstract}

Key Words: Seed treatment, soil application, insecticides, stemfly and pod borers, mungbean.

\section{Introduction}

Munghean is an important pulse crop grown in Bangladesh for its high price, easy digestibility, good flavour and high protein content. It occupies about $10 \%$ of the total area under pulses and contributes $8.5 \%$ of the total pulse production in the country (BBS, 2004).

Munghean is severely damaged by a number of insect pests. Among them, stemfly (Opheomyia phaseoli) and pod borers (Helicoverpa armigera \& Maruca vitrata..) are considered to he major pests. Insecticides are usually applied as foliar application for the control of these pests. An attempt was made to evaluate the relative efficacy of some insecticides as seed treatment and soil application against these pests.

\section{Materials and Method}

The experiments were conducted at Agricultural Research Station, Burirhat, Rangpur during the cropping seasons of mungbean from August to December of

\footnotetext{
${ }^{1-3}$ Scientific Officer, ARS, BARI, Burirhat, Rangpur, ${ }^{4}$ Senior Scientific Officer, RARS, BARI, Ishurdi, Pabna, ${ }^{5}$ Secior Monitoring Officer, RDRS, Rangpur, Bangladesh.
} 
2004 - 05 and 2005 - 06. The investigation was made to find out the most effective insecticides in seed treatment and soil application for controlling the stemfy and pod borers of mungbean. Carbofuran 5 (3 (Furadan 5G). Carbosulfan 6G (Marshal 6G) and Phenyl Pyrazol 3G (Regent 3G) @ 2 and 4 \% were used in seed treatment and the same insecticides at 0.75 and $1 \mathrm{~kg}$ a.i. /ha were applied in the soil with untreated control.

The experiments were laid out in RCBD with three replicates. The unit plot size was $3 \mathrm{~m} \times 2.1 \mathrm{~m}$ with an inter-plot distance of Im and inter block distance of $1.5 \mathrm{~m}$. The spacing was $30 \mathrm{~cm}$ between rows and $10 \mathrm{~cm}$ between plants. For seed treatments, required quantity of insecticides was mixed with ample water to prepare slurry with which seeds were treated (Sinha et al., 1993). The granules for soil application were applied in the soil below the seed furrows at the time of sowing. At harvest, 10 randomly selected plants from each plot were uprooted and stems were split opened by a scalpel for recording the extent of stem tunneling by stemfly. The lengths of the stem were measured by a scale. From these data, percentage of stemfly infested plants and percentage of stem tunneling were calculated. Percent stem tunneling was calculated by following way -

Stem tunneling $(\%)=\frac{\text { Length of stem tunneling }}{\text { Total length of stem }} \times 100$

Numbers of pod borer infested pods were also counted at harvest. The yield of rnunghean seeds was recorded. Finally the data were analyzed statistically by using MSTAT programme and compared by DMRT. Correlation regression analysis was done to determine the relationship between stem tunneling and yield of mungbean as affected by each insecticidal treatment.

\section{Results and Discussion}

Stemfly infestation: The data presented in Table 1 and 2 show that the percentage of stem fly, infested plants in the treated plots were significantly lower than the control. In 2004, the soil application of Carbofuran @ 0.75 kg and 1 kg a.i./ha recorded the least plant damage (20\%) by stemfly and the seed treatment with 2 and $4 \%$ Carbofuran resulted $40 \%$ damage, which was double than in soil treatment. In 2005, seed treatment with Carbosulfan (2\%) showed the least damage (13.33\%) followed by (33.33 \%) with Carbosulfan (4\%) and Carbofuran (2\%) and (4\%), respectively. Highest percentage (86.67 - $93.33 \%)$ of stemfiy infestation was obtained from the untreated control plots in both the years (Table 1 \& 2). Bear et al. (1993) reported that Carhofuran and Phorate at 0.75 and $1 \mathrm{~kg}$ a.i./ha were the most effective insecticide against Opheomyia phaseoli in peas. The effectiveness of soil application of Carbofuran against stem fly has also been reported by Ambekar et al. (1984) and Ramadoss \& Sivaprakasam (1988).

Stem tunneling by stemfly: The larvae of stemfly made tunnel by feeding inside the stem of munghean plant. Percentage of stem tunneling was found to be major 
factor for yield reduction by stemfly. The stem tunneling in plants varied significantly $(\mathrm{p}<0.05)$ due to the application of insecticides. In 2004, the lowest stem tunneling (5.92 \%) was obtained from the plants of Carhofuran ( $1 \mathrm{~kg}$ a.i./ha) treated plot followed by Carbofuran $(0.75 \mathrm{~kg}$ a.i./ha). The seed treatment with Carbofuran (2\% and $4 \%$ ) recorded the same level of stem tunneling, which was significantly higher than that of its soil application (Table 1). In 2005, slight difference of stem tunneling was found. Soil application of Carbofuran at $1 \mathrm{~kg}$ a.i./ha recorded the least stem tunneling (7.86 - $10.33 \%)$ followed by the seed treated with Carbofuran (2\%) (Table 2). The highest stem tunneling at 26.90 to 27.09 percent was found in the control plots in both the years (Table $1 \& 2$ ). According to Hussain (1978) Carbofuran granules as soil application significantly reduced the damage of stemfly infestation. Zahid and Sardar (2005), however, reported soil application of Carbofuran and Carbosulfan was the effective measure to control stemfly and pod borers on blackgram. Similar results that with Carbofuran granules were obtained by Babu and Rajsaekaran (1981) and Gupta \& Singh (1984). Saxena el al. (1975) reported effective control with Carbofuran seed treatment. Sinha et al. (1993) reported that both seed treatment and soil application of Carbofuran was quite effective against stemfly (Melanagromyzu phuseoli). In the present study, Carbofuran granules both seed treatment and soil application proved effective in controlling the stemfly.

Table 1.Treatrnent of insecticides on the incidence of stemfly, pod borers and yield of munghean during 2004-2005.

\begin{tabular}{l|l|l|l|l}
\hline \multicolumn{1}{c|}{ Treatment } & $\begin{array}{c}\text { Stemfly } \\
\text { infected plants } \\
\text { at harvest (\%) }\end{array}$ & $\begin{array}{c}\text { Stem } \\
\text { tunneling at } \\
\text { harvest (\%) }\end{array}$ & $\begin{array}{c}\text { Pod borers } \\
\text { infestation } \\
(\%)\end{array}$ & $\begin{array}{c}\text { Grain yield } \\
\text { (kg/ha) }\end{array}$ \\
\hline Seed treatment & & & \\
\hline Carbofuran (2\%) & $40.00 \mathrm{~d}$ & $8.24 \mathrm{cde}$ & 17.03 & $925 \mathrm{~b}$ \\
Carbofuran (4\%) & $40.00 \mathrm{~d}$ & $8.07 \mathrm{cde}$ & 17.90 & $945 \mathrm{~b}$ \\
Carbosulfan (2\%) & $53.33 \mathrm{bc}$ & $12.07 \mathrm{bcde}$ & 18.14 & $846 \mathrm{c}$ \\
Carbosulfan (4\%) & $53.33 \mathrm{bc}$ & $12.05 \mathrm{hcde}$ & 17.45 & $864 \mathrm{c}$ \\
Phenyl pyrazol (2\%) & $53.33 \mathrm{bc}$ & $13.05 \mathrm{bed}$ & 19.22 & $822 \mathrm{ed}$ \\
Phenyl pyrazol (4\%) & $46.67 \mathrm{~cd}$ & $11.99 \mathrm{bcde}$ & 17.85 & $815 \mathrm{~cd}$ \\
Soil application & & & & \\
Carbofuran @ 0.75 kg a.i./ha & $20.00 \mathrm{e}$ & $6.75 \mathrm{de}$ & 16.96 & I 245 a \\
Carbofuran @ 1 kg a.i./ha & $20.00 \mathrm{e}$ & $5.92 \mathrm{e}$ & 16.86 & $1294 \mathrm{a}$ \\
Carbosulfan @ 0.75 kg a.i./ha & $53.33 \mathrm{~b}$ & $13.48 \mathrm{bc}$ & 18.09 & $776 \mathrm{~cd}$ \\
Carhosulfan @ 1 kg a.i./ha & $60.00 \mathrm{~b}$ & $14.92 \mathrm{~b}$ & 18.54 & $704 \mathrm{~d}$ \\
Phenyl pyrazol @ 0.75 kg a.i /ha $53.33 \mathrm{bc}$ & $12.16 \mathrm{bcde}$ & 19.21 & $822 \mathrm{~cd}$ \\
Phenyl pyrazol @ 1 kg a.i /ha & $53.33 \mathrm{bc}$ & $11.39 \mathrm{bcde}$ & 18.81 & $839 \mathrm{c}$ \\
Control & $86.67 \mathrm{a}$ & $27.09 \mathrm{a}$ & 22.15 & $546 \mathrm{e}$ \\
\hline
\end{tabular}

In a column means followed by common letter (s) are not significantly different at $5 \%$ level. 
Pod damage by the borers: The caterpillars of $H$. armigera feed on leaves, buds, flowers, and voraciously on pods. The caterpillars of Maruca vitrata damage flower buds, flower, and developing pods. As for pod borer damage, the data presented in Table 1 show that insecticidal treatment did not differ significantly compared to the control in 2004, but there was significant difference (9.64-13.27 \%) in 2005 (Table 2). Seed treatment and soil application of granular insecticides did not affect on pod borer damage on mungbean as stemfly infestation. This was due to not effectiveness of granular insecticides in both seed treatment and soil application on the pod borer attack. It might be due to pod borers attack to mungbean in the flowering and pod formation stage. Sahoo and Senapati (2000) reported that $H$. armigera was observed in the flowering stage and $M$. testulalis was the dominant pest in the grain filling stage in pigeonpea. The highest activity of pod borer was during pod formation stage in chickpea (Metho and Singh, 1983). To reduce pod borers attack, spray schedules should be made at flower initiation and pod formation stages.

Table 2. Treatment of insecticides on the incidence of stemfly, pod borers and yield of munghean during 2005-2006.

\begin{tabular}{l|l|l|l|l}
\hline \multicolumn{1}{c|}{ Treatments } & $\begin{array}{c}\text { Stemfly } \\
\text { infected } \\
\text { plants at } \\
\text { harvest (\%) }\end{array}$ & $\begin{array}{c}\text { Stem } \\
\text { tunneling at } \\
\text { harvest (\%) }\end{array}$ & $\begin{array}{c}\text { Pod borers } \\
\text { infestation } \\
(\%)\end{array}$ & $\begin{array}{c}\text { Grain yield } \\
(\mathrm{kg} / \mathrm{ha})\end{array}$ \\
\hline Seed treatment & & & \\
Carbofuran (2\%) & $33.33 \mathrm{~cd}$ & $9.83 \mathrm{de}$ & $11.42 \mathrm{~b}$ & $1027 \mathrm{~b}$ \\
Carbofuran (4\%) & $33.33 \mathrm{~cd}$ & $8.33 \mathrm{e}$ & $13.20 \mathrm{~b}$ & $1250 \mathrm{a}$ \\
Carbosulfan (2\%) & $13.33 \mathrm{~d}$ & $13.60 \mathrm{~cd}$ & $10.53 \mathrm{~b}$ & $959 \mathrm{bed}$ \\
Carbosulfan (4\%) & $33.33 \mathrm{~cd}$ & $14.53 \mathrm{c}$ & $9.64 \mathrm{~b}$ & $83 \mathrm{bcde}$ \\
Phenyl pyrazol (2\%) & $60.00 \mathrm{abc}$ & $15.81 \mathrm{c}$ & $10.90 \mathrm{~b}$ & $843 \mathrm{de}$ \\
Phenyl pyrazol (4\%) & $60.00 \mathrm{abc}$ & $14.96 \mathrm{c}$ & $11.50 \mathrm{~b}$ & $862 \mathrm{ede}$ \\
Soil application & & & & \\
Carbofuran @ 0.75 kg a.i./ha & $53.33 \mathrm{be}$ & $8.16 \mathrm{e}$ & $11.54 \mathrm{~b}$ & $1050 \mathrm{~b}$ \\
Carbofuran @ 1 kg a.i./ha & $60.00 \mathrm{abc}$ & $7.86 \mathrm{e}$ & $0.21 \mathrm{~b}$ & $11267 \mathrm{a}$ \\
Carbosulfan @ 0.75 kg a.i./ha & $66.66 \mathrm{abc}$ & $16.90 \mathrm{be}$ & $10.73 \mathrm{~b}$ & $850 \mathrm{de}$ \\
Carhosulfan @ 1 kg a.i./ha & $60.00 \mathrm{abc}$ & $19.38 \mathrm{~b}$ & $9.88 \mathrm{~b}$ & $805 \mathrm{e}$ \\
Phenyl pyrazol @ 0.75 kg a.i /ha & $73.33 \mathrm{ab}$ & $15.66 \mathrm{c}$ & $11.91 \mathrm{~b}$ & $827 \mathrm{de}$ \\
Phenyl pyrazol @ 1 kg a.i /ha & $66.66 \mathrm{abc}$ & $16.16 \mathrm{c}$ & $13.27 \mathrm{~b}$ & $820 \mathrm{de}$ \\
Control & $93.33 \mathrm{a}$ & $26.90 \mathrm{a}$ & $27.71 \mathrm{a}$ & $557 \mathrm{f}$ \\
\hline
\end{tabular}

In a column means followed by common letter (s) are not significantly different at $5 \%$ level. 
Table 3. Economic evaluation of insecticides on grain yield of mungbean based on benefit cost ratio (BCR) during 2004-05.

\begin{tabular}{|c|c|c|c|c|c|c|c|c|c|}
\hline Treatments & $\begin{array}{c}\text { Quantity of } \\
\text { insecticides } \\
(\mathrm{kg} / \mathrm{ha})\end{array}$ & $\begin{array}{c}\text { Cost of } \\
\text { insecticides } \\
\text { (Tk.) }\end{array}$ & $\begin{array}{c}\text { Labour } \\
\text { charge } \\
\text { (Tk.) }\end{array}$ & $\begin{array}{c}\text { Total cost } \\
\text { (Tk.) }\end{array}$ & $\begin{array}{c}\text { Total } \\
\text { yield } \\
\text { (kg/ha) }\end{array}$ & $\begin{array}{c}\text { Additional } \\
\text { yield over } \\
\text { control } \\
(\mathrm{kg} / \mathrm{ha})\end{array}$ & $\begin{array}{c}\text { Cost of } \\
\text { additional } \\
\text { yield (Tk.) }\end{array}$ & $\begin{array}{l}\text { Net } \\
\text { profit } \\
\text { (Tk.) }\end{array}$ & BCR \\
\hline \multicolumn{10}{|l|}{ Seed treatment } \\
\hline Carbofuran (2\%) & 2.3 & 276 & 480 & 756 & 925 & 379 & 13265 & 12509 & 16.54 \\
\hline Carbofuran (4\%) & 4.6 & 552 & 480 & 1032 & 945 & 399 & 13965 & 12933 & 12.53 \\
\hline Carbosulfan (2\%) & 2.3 & 276 & 480 & 756 & 822 & 300 & 9660 & 8904 & 12.88 \\
\hline Carbosulfan (4\%) & 4.6 & 552 & 480 & 1032 & 864 & 318 & 11130 & 10098 & 9.78 \\
\hline Phenyl pyrazol (2\%) & 2.3 & 276 & 480 & 756 & 846 & 276 & 10500 & 9744 & 11.77 \\
\hline Phenyl pyrazol (4\%) & 4.6 & 552 & 480 & 1032 & 815 & 279 & 9765 & 8733 & 8.46 \\
\hline \multicolumn{10}{|l|}{$\underline{\text { Soil application }}$} \\
\hline Carbofuran@0.75 kg a.i./ha & 15 & 1800 & 480 & 2280 & 1245 & 699 & 24465 & 22185 & 9.73 \\
\hline Carbofuran@1 kg a.i./ha & 20 & 2400 & 480 & 2880 & 1294 & 748 & 26180 & 23300 & 8.09 \\
\hline Carbosulfan @ 0.75 kg a.i./ha & 12.5 & 1500 & 480 & 1980 & 776 & 230 & 8050 & 6070 & 3.06 \\
\hline Carhosulfan@ 1 kg a.i./ha & 16.66 & 1999 & 480 & 2479 & 704 & 158 & 5530 & 3050 & 1.23 \\
\hline Phenyl pyrazol @0.75 kg a.i /ha & 25 & 3000 & 480 & 3480 & 822 & 275 & 9660 & 6180 & 1.77 \\
\hline Phenyl pyrazol@1 kg a.i /ha & 33.33 & 3999 & 480 & 4479 & 839 & 293 & 10255 & 5775 & 1.28 \\
\hline Control & - & - & - & - & 546 & - & - & - & - \\
\hline
\end{tabular}

Mungbean

$=T \mathrm{k} .35 / \mathrm{kg}$

Furadan (Carbofuran) 5G $\quad=$ Tk. 120/kg

Marshal (Carbosulfan) 6G $=$ Tk. 120/kg

Regent (Pheyl phrazol) 3G = Tk. 120/kg

Labour charge $\quad=$ Tk. 120/Labour 
Mungbean yield and economic evaluation of insectidial treatments: Yield of munghean seed or grain obtained from the treated insecticides against stemfly and pod horers differs significantly $(\mathrm{p}<0.05)$ (Table $\mathrm{l}$ and 2 ). In 2004, grain yield of mungbean was the highest from $1245 \mathrm{~kg} / \mathrm{ha}$ to $1294 \mathrm{~kg} / \mathrm{ha}$ in the plot treated with soil application of Carbofuran @ 0.75 and $1 \mathrm{~kg}$ a.i.//ha. The seed treatment with the same insecticide ( $2 \%$ and $4 \%$ ) showed the yield ranged from $925 \mathrm{~kg} / \mathrm{ha}$ to $945 \mathrm{~kg} / \mathrm{ha}$ next to soil application of Carbofuran and which was statistically similar (Table 1). In 2005, the highest yield of $1267 \mathrm{~kg} /$ ha was found in soil application of Carhofuran (1 kga.i./ha), which was statistically similar (1250 $\mathrm{kg} / \mathrm{ha}$ ) to seed treatment with Carhofuran (4\%). Seed treated with Carbofuran (2\%) showed the yield (1027 kg/ha) next to the seed treatment with (Carbofuran (4\%) followed by (1050 kg/ha) the soil application of Carbofuran $(0.75 \mathrm{~kg}$ a.i./ha) (Table 2). The treated plots showed 21 or $57 \%$ and 30 to $56 \%$ yield increase over control in 2004 and 2005, respectively. Babu and Rajasekaran (1981) evaluated seven insecticides against 0 . Phuseoli on cowpea of which soil application of Carbofuran 5G @ $1 \mathrm{~kg}$ a.i./ha at the time of sowing reduced stemfly infestation and increased the yield. Singh et al. (1988) also reported the similar result on pea. Shinha et al. (1993) reported that productivity of pea was the maximum under the treatment with Carbofuran (@2\% and 4\%) and soil

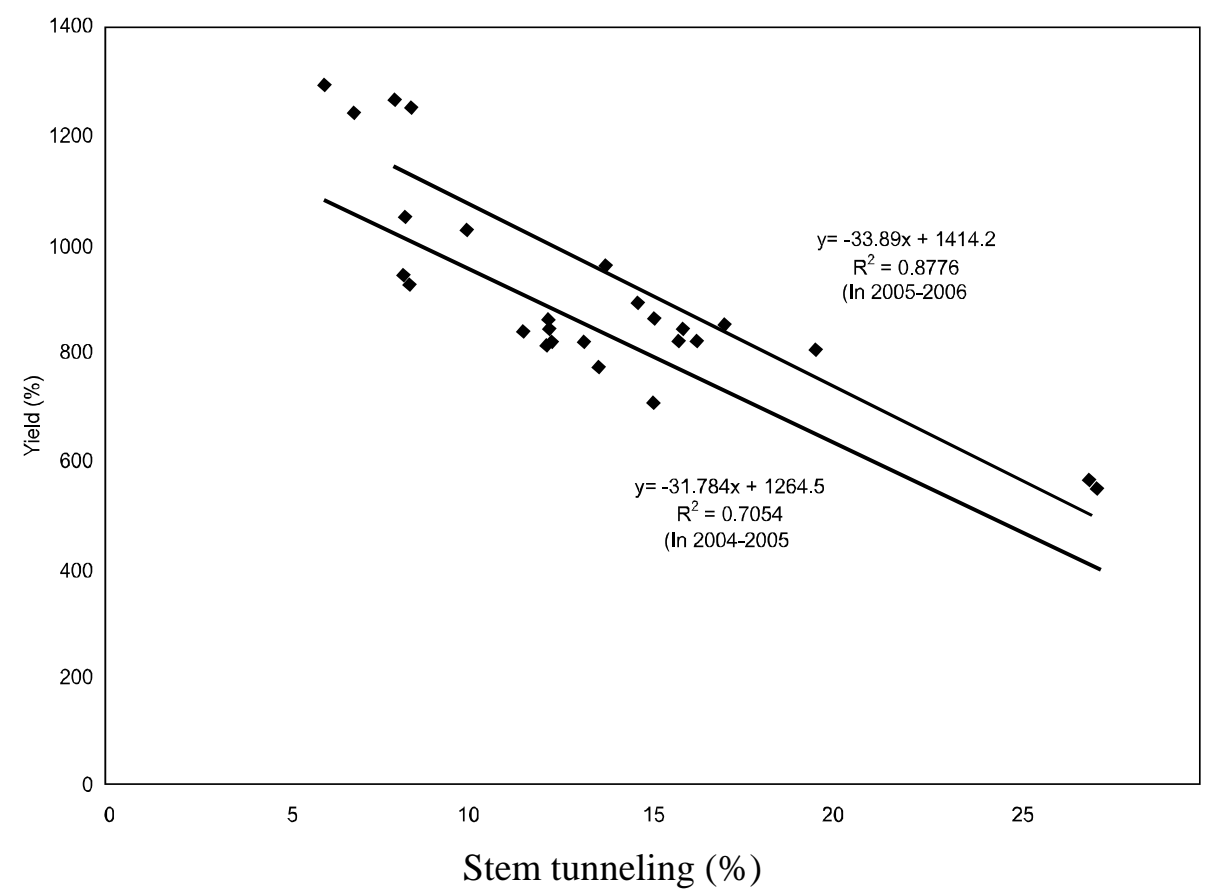

Fig. 1. Relationship between stem tunneling and yield of mungbean treated with different insecticides against stemfly in 2004-2005 \& 2005-2006. 
Table 4. Economic evaluation of insecticides on grain yield of mungbean based on benefit cost ratio (BCR) during 2005-06.

\begin{tabular}{|c|c|c|c|c|c|c|c|c|c|c|}
\hline Treatments & $\begin{array}{c}\text { Quantity of } \\
\text { insecticides } \\
\text { (kg/ha) }\end{array}$ & $\begin{array}{c}\text { Quantity of } \\
\text { insecticides } \\
\text { of } 2 \text { sprays } \\
\text { (L) }\end{array}$ & $\begin{array}{c}\text { Cost of } \\
\text { insecti- } \\
\text { cides } \\
\text { (Tk.) }\end{array}$ & $\begin{array}{c}\text { Labour } \\
\text { charge } \\
\text { (Tk.) }\end{array}$ & $\begin{array}{l}\text { Total } \\
\text { cost } \\
(\mathrm{Tk} .)\end{array}$ & $\begin{array}{l}\text { Total } \\
\text { yield } \\
\text { (kg/ha) }\end{array}$ & \begin{tabular}{|c|}
$\begin{array}{c}\text { Additional } \\
\text { yield over } \\
\text { control } \\
(\mathrm{kg} / \mathrm{ha})\end{array}$ \\
\end{tabular} & \begin{tabular}{|c|} 
Cost of \\
additional \\
yield (Tk.)
\end{tabular} & \begin{tabular}{|c} 
Net \\
profit \\
(Tk.)
\end{tabular} & BCR \\
\hline \multicolumn{11}{|l|}{$\underline{\text { Seed treatment }}$} \\
\hline Carbofuran (2\%) & 2.3 & 0.5 & 826 & 720 & 1546 & 1027 & 470 & 16450 & 14904 & 9.64 \\
\hline Carbofuran (4\%) & 4.6 & 0.5 & 1102 & 720 & 1822 & 1250 & 693 & 24255 & 22403 & 12.29 \\
\hline Phenyl pyrazol (2\%) & 2.3 & 0.5 & 826 & 720 & 1546 & 843 & 286 & 10010 & 8464 & 5.47 \\
\hline Phenyl pyrazol (4\%o) & 4.6 & 0.5 & 1102 & 720 & 1822 & 862 & 305 & 10675 & 8853 & 4.85 \\
\hline \multicolumn{11}{|l|}{$\underline{\text { Soil application }}$} \\
\hline Carbofuran@0.75 kg a.i./ha & 15 & 0.5 & 2350 & 720 & 3070 & 1050 & 493 & 17255 & 14185 & 4.62 \\
\hline Carbofuran@1 kg a.i./ha & 20 & 0.5 & 2950 & 720 & 3670 & 1267 & 710 & 24850 & 21180 & 5.77 \\
\hline Phenyl pyrazol @1 kg a.i /ha & 33.33 & 0.5 & 4500 & 720 & 5270 & 820 & 263 & 9205 & 3935 & 0.74 \\
\hline Control & - & & - & - & - & 557 & - & - & - & - \\
\hline Mungbean & \multicolumn{10}{|l|}{$=\mathrm{Tk} .35 / \mathrm{kg}$} \\
\hline Furadan (Carbofuran) 5G & \multicolumn{10}{|c|}{$=\mathrm{Tk} \cdot 120 / \mathrm{kg}$} \\
\hline Marshal (Carbosulfan) 6G & \multicolumn{10}{|c|}{$=$ Tk. $120 / \mathrm{kg}$} \\
\hline Regent (Pheyl phrazol) 3G & \multicolumn{10}{|c|}{$=\mathrm{Tk} \cdot 120 / \mathrm{kg}$} \\
\hline Ripcord (Cypermethrin) 10 EC & \multicolumn{10}{|c|}{$=$ Tk. 1100/L } \\
\hline Labour charge & \multicolumn{10}{|c|}{$=$ Tk. 120/Labour } \\
\hline
\end{tabular}


treatment with (Carhofuran (1 kg a.i./ha). According to Zahid and Sardar (2005), Carbofuran and Carbosulfan granules as soil application significantly reduced the damage of stemfly and pod borers and produced maximum yield in blackgram. This evidence supported the increased yield of munghean in the present study by the seed treatment and soil application of Carbofuran and Carbosulfan. This result also shows that there is a significant negative correlation and linear relationship between stem tunneling and yield (Fig. I). It indicated that the reduction of yield is associated with an increase in stem tunneling. Therefore, mungbean crop should be controlled from stemfly during early growth stage to avoid yield reduction. $\mathrm{R}^{2}=0.7054(2004-2005)$ and 0.8776 (2005 2006) are also significant in both years (Fig. 1).

In 2004, the highest BCR (16.54) was obtained from seed treatment with Carhofuran (2\%) followed by (12.88) seed treatment with Carbosulfan (2\%). In 2005, the highest BCR (12.29) was obtained from the seed treated with Carbofuran (4\%) followed by (9.64) the seed treated with Carhofuran (2\%). Seed treatment with Carbofuran (2\%) and Carbosulfan (2\%) were also proved quite economical in 2004 and 2005, respectively. Sinha et al. (1993) evaluated Carhofuran and Phorate as soil and seed treatments for the control of Melanagromyza phaseoli (L)pheomyia phaseoli) on peas. Seed treatment with both insecticides at 2 and $4 \%$ was effective against the pests and more economical than soil treatment. The maximum cost benefit ratio was obtained from seed treatment with $2 \%$ Carbofuran.

\section{References}

Ambekar. J. S., M. E. Patil, D. B. Pawer, D. N. Gandhale and R. N. Pokharkar. 1984. A note on the control of stemfly (Opheomyia phaseoli Tryon) on peas (Pisum sativum L). South Indian Hort. 32 (6): 377-378.

Babu. P. C. S. and B. Rajasekaran. 1981. A note on the control of stemfly. Ophiomyia phaseoli on cowpea, (Vigna uguculata L.). Madras Agric. J. 68 (3): 205-206.

Bangladesh Bureau of Statistics (BBS). 2004. Statistical Yearbook of Bangladesh. Ministry of Planning, Government of People's Republic of Bangladesh, Dhaka. p 141.

Bear, K. S., G. S. Dhillon, M. Singh. and M. Singh. 1993. Control of pea stemfly. Opheomyia phaseoli Tryon in early crop of pea. Indian J. Ent. 55 (2): 210 211.

Gupta. P. K. and J. Singh. 1984. Control of Ophiomyia phaseoli. in green gram with granular insecticides. Indian, J. Agric. Sci. 54 (4): 3210.

Hussain, M. M .D. 1978. Soil application of granules to control bean fly (Ophiomyia phaseoli. Agromycidae. Diptera) infesting Mean (Phaseolus vulgaris. L.) in Maharashtra. J. Moharastra Agril. Univ. 20 (1): 83-84. 
Metho, D. N. and K. M. Singh. 1983. Succession of insect pests in chickpea. (Ccer arirtinum Linn. Indian J. Entomol. 45 (4): 377-383.

Rarnadoss, S. and K. Sivaprakasam. 1988. Control of root rot (Macrophomina phuseolina) and (Opheomyia phaseoli Tryon) on cowpea. Madras Agric. J. 75 (3 4): 133-138.

Saxena. H. P.. A. Phokela and Y. Singh. 1975. Effectiveness of Carbofuran as seed treatment for controlling pest complex of mung (Phaseolus aureus) and (Phaseolus vulgaris). Entomologist's Newsl. 6 (14): 27 - 28.

Shahoo. B. K. and B. Senapati. 2000. Relative abundance of pod borer species in different maturing pigeon pea varieties in costal belt of Orissa. Indian J. Plant Prot. 28 (2): 192-994.

Singh. H. M., S. M. A. Rizivi, R. Singh and R. Singh. 1988. Insectidal control of pea stemfly, Ophiomyiaph phaseoli. (Tryon). Indian J. Plant Prot. 16 (1): 4 1-43.

Sinha, M. M., S. F. Hameed, D. N. Metito and B. S. Jha. 1993. Effectiveness of seed and soil treatment with some insecticides against stemfly, Melanagromyza phaseoli and pod borer, Etiella zinckenella T. on pea (Pisum sativum L.). Indian J. Ent. 55 (3): 297-302.

Zahid. M. A. and M. A. Sardar. 2005. Effect of some insecticides and sowing times for the control of stemfly and pod borers in blackgram, Bangladesh. J. Agril. Res. 30 (3): 395-404. 